\title{
THE MARK OF THE BEAST, REVELATION 13:16
}

\section{Edwin A. Judge}

The mark on the right hand (=wrist?) or the forehead gives one admission to the market (Rev. 13:16). Is this an imaginary scene, symbolic of something else, or can one envisage an actual practice of market control based on marks?

A symbolic meaning is not hard to find. The redeemed are sealed upon their foreheads (Rev. 7:3). Those who conquered at Pergamum were promised a white stone with a new name on it (Rev. 2:17). The devotee of Asclepius, Aelius Aristides, seems to have worn a secret symbol of his god, to which he attributed his rhetorical success, and had received a new name. ${ }^{1}$ Revelation repeatedly refers to the name of God written on the forehead of believers (3:12, 14:1, 22:4).

This may reflect the golden rosette fixed to Aaron's turban (Ex. 28.36-38) engraved 'Holy to the Lord'. Every Israelite could claim to 'bear God's name' (Dn. 9:19, cf. Nu. 6:27, Dt. 28:10, Is. 43:7, 63:8, and Jas 2:7). In Ezekiel 9:2-4 a man clothed in linen puts a mark with ink on the foreheads of those who are to be spared. As for the combination of hand and forehead, one may compare the literal binding on of the law (Ex. 13:9, Dt. 6:8, Mt. 23:5). The mark of the beast may therefore be conceived simply as the visionary counterpart to this tradition of a public sign of commitment to God.

But the visions of Revelation keep disconcertingly coming down to earth. The woman clothed with the sun and the great red dragon are both explicitly 'in heaven' (12:1,3). But their struggle soon ends up on earth (12:16), and the beast's arrival by sea is viewed from the beach $(12: 17,13: 1)$. The second beast deputizes for the first, and imposes his cult on people (13:12). It is dramatically staged, with fireworks

${ }^{1}$ Hymn to Asclepius 6.69; Sacred Tales 4.26.518. 
(13:13) and ventriloquism (13:15) giving the statue an appearance of life. ${ }^{2}$

It is still reasonable of course to argue that these are imaginary details, with only symbolic force. ${ }^{3}$ But that force may have been partly derived from contemporary parallels. Although the text does not at first say so, it is apparent that to get the mark that lets you into the market you had to worship the beast $(13: 15-16,20.4)$. If you refused the test you were killed (12:15), and a worse fate awaited the believer who took it (14:9-11).

The practical outcome would have been to exclude believers altogether from the trading community-an implied apartheid policy such as was eventually put into regular effect. ${ }^{4}$

In AD 303-4 we know from a contemporary papyrus letter that a test of sacrifice (in the form of a pinch of incense on the altar?) was required to gain access to the courts of law. ${ }^{5}$ In the time of Domitian (whose emphasis on his own divinity is commonly thought to lie behind Revelation) a large temple to him, with colossal statue, was erected in Ephesus (Roman capital of Asia, to which the book is addressed) to the west of the upper market, where you would pass if coming up from the harbour. Perhaps they required everyone to sacrifice to Domitian before entering the market? But if so, what sort of mark could have been used as evidence?

The term $\chi \alpha \dot{p} \rho \alpha \mu \alpha$ (Rev. 13:16) ordinarily implies an engraved mark or a seal impression, or inscription. The Roman government under Augustus had already been issuing (inscribed?) tesserae (tiles) as proof of entitlement to the periodic grain dole. ${ }^{6}$ Presumably you got one when marked off on the roll, and then gave your tile in at the granary. In the famine at Edessa in AD 499-500 the governor 'sealed many of

\footnotetext{
${ }^{2}$ S.J. Scherrer, 'Signs and wonders in the imperial cult: a new look at a Roman religious institution in the light of Rev.13.13-15', JBL 103/4 (1984) 599-610: S.R.F. Price, Rituals and Power: The Roman Imperial Cult in Asia Minor (Cambridge, CUP 1984) 191-206.

${ }^{3}$ So J.P.M. Sweet, Revelation (London, SCM 1979).

${ }^{4} \mathrm{~S}$. Mitchell, 'Maximinus and the Christians in $\mathrm{AD}$ 312: 'A new Latin inscription', JRS 78 (1988) 105-124.

5P.Oxy. 2601.

'Suetonius, Aug. 40.2, 42.3.
} 
them on their necks with leaden seals, and gave each of them a pound of bread a day $; 7$ but how did that stop them coming back for more? Neither of these systems fits a mark made on the hand or forehead.

Tattooing was used by barbarian peoples as a status mark. ${ }^{8}$ Judaism and other oriental cults used it as a sign . of dedication. A devotee of Cybele and Attis is 'sealed' by tattooing. ${ }^{9}$ A Byzantine chariot-driver had his forehead tattooed with a cross. ${ }^{10}$ Branding on the forehead was used as a penalty for runaway slaves, being displaced after Constantine by a metal collar. ${ }^{11}$ The Greek tradition otherwise recoiled from the branding of slaves. 'Do not brand your servant with marks that insult him', says pseudo-Phocylides, the sixthcentury elegist. ${ }^{12}$ But a brand-mark could easily be imitated with ink. In the first century Satyricon of Petronius, Eumolpus proposes to fake one as a disguise:

Let him shave not just your heads, but your eyebrows too, rightaway. Then I shall inscribe some neat lettering on your foreheads to make it look as though you had been branded as a punishment. ${ }^{13}$

We may imagine, then, those who entered the market of Ephesus having first to make their sacrifice, and then receiving their mark in ink on wrist or forehead, just as in Ezekiel 9:2-6. There is no evidence that such a test was actually applied at this time. But there is just enough miscellaneous information on comparable practices for us to say that this is what might have sprung to mind for those listening to Revelation, when they heard that to enter the market you had first to receive the mark of the beast. ${ }^{14}$

\footnotetext{
${ }^{7}$ Cited in Peter Garnsey, Famine and Food Supply in the Graeco-Roman World: Responses to Risk and Crisis (Cambridge, CUP 1988) 4.

${ }^{8}$ Xenophon, Anabasis 5.4.32; Diodorus Siculus 14.30.7; Pliny, Natural History 22.1.2.

${ }^{9}$ Prudentius, Peristephanon 10.1076-90.

${ }^{10} \mathrm{~F}$.J. Dölger, Antike und Christentum, s.o.

${ }^{11}$ As with the archdeacon's slave, G.H.R. Horsley, New Docs 1, no. 91.

${ }_{12}^{12}$. Wiedemann, Greek and Roman Slavery (London, Croom Helm 1981) no. 207.

13\#103 cited Wiedemann, no. 218.

${ }^{14}$ Notes of a paper given to the Continuing Education Seminar of the Society for Early Christianity, Macquarie University, 28th April, 1990. An invaluable stock-taking of the historical background is given by C.J. Hemer, The Letters to the Seoen Churches of Asia in their Local Setting (Sheffield, JSOT Press 1986).
} 